\title{
Study of Learning Effects of Agricultural Mechatronics Modular-Course on Thematic Practice
}

\author{
Chih-Ho Nien, Yu-I Wang, Hung-Yi Lin, and Chin-Wen Liao
}

\begin{abstract}
This study aimed to review the effects on skill-based agricultural senior high school students' learning after agricultural mechatronics modular-course was applied to their thematic practice. Statistical data were collected by employing test papers. Paired sample t-test was adopted to draw a comparison between precourse learning effects and postcourse learning effects. Analysis results indicated that there is significant difference in $\mathbf{4 0}$ skill-based senior high school students' learning effects after those students took the modular-course. It appears that agricultural mechatronics modular-course has a positive effect on students' learning and unit course "applications of sensor in agriculture" is popular with students.
\end{abstract}

Index Terms-Mechatronics, thematic practice, learning effect.

\section{INTRODUCTION}

\section{A. Research Background and Motive}

Taiwan has transformed from agricultural society to industrial and commercial society for years, but the development of agriculture still needs people's attention because food is an important issue to a nation's development. Agricultural education in Taiwan was founded during the period of Japanese occupation. However, when the economic development focus moved to industrial and commercial development, the proportion of agricultural output in national economy of Taiwan also declined. Some researchers have pointed out that fewer and fewer people are willing to work in agricultural industry, and which causes entire agricultural education system to be mired in difficulties because of low qualities of students, enrollment on the decrease, and graduates' having difficulty in getting a job [1].

To raise cost-effectiveness of agriculture needs innovative technology. Through the application of mechatronics, agricultural production can be planned and managed more sophisticatedly based on automation and high-quality agriculture. Since semiconductor process made great progress in silicon mechanical structure, there have been many new applications embraced by the integration and innovation of mechatronics such as a system that has integrated mechanical, physical, and chemical sensing technology and can process light, electrical, magnetic, sonic, temperature, and biochemical detection. Reported that compared with traditional machinery process regarding production technology, mechatronics has many strengths

Manuscript received August 21, 2018; revised December 23, 2018.

The authors are with the National Changhua University of Education, Taiwan (e-mail: sriver0217@hotmail.com). such as high precision, batch production, micromation, and low costs, and its components help deliver benefits like fast response and low energy consumption [2].

In a study, several authors have suggested that in skill-based agricultural senior high schools, students can learn teamwork and people skills through thematic practice [3]. By learning those, they may cultivate logical and intuitive thinking, will power, the sense of responsibility, creativity, and inquisitiveness. When those students become fresh graduates, they may utilize their knowledge and skills to collaborate with other people and adapt themselves to new circumstances. Thematic practice should be able to train students not only to organize theories, knowledge, and skills they learned in the past for the goals of understanding what industries need and of working in the real world but also to discern their own interests and goals. By collaborating with other students during thematic practice, they may learn critical thinking, problem-analyzing, and problem-solving so that they can fit in with rapidly changing society [4].

\section{B. Research Purpose}

This study was performed with 4 teachers' assistance in a department of bio-mechatronics in a national skill-based senior high school in Yunlin, for a duration of 12 weeks. Purpose of this study was to investigate the learning effects after senior high school students took agricultural mechatronics modular-course.

\section{RESEARCH DESIGN AND IMPLEMENTATION}

Research subjects were 40 seniors of bio-mechatronics department in a national skill-based senior high school in Yunlin.

This study designed corresponding classes and assessment scales based on agricultural mechatronics modular-course. Then a research of teaching-learning was conducted to evaluate students' learning effects by using a precourse assessment scale and a postcourse assessment scale.

\section{A. Curriculum Planning and Design}

\section{1) Course objective and learning activities objective}

This study proposed course objective and learning activities objective according to agricultural mechatronics modular-course program. Learning activities objective corresponded to course design of 4 units: incorporation of make education into agricultural technology, basic cultivation techniques, applications of mechatronics in farm facilities, and applications of sensor in agriculture.

\section{2) Course design}

There were 4 course units designed for agricultural 
mechatronics modular-course. Each unit required 3 weeks, 3 hours per unit weekly. 4 units required 36 hours in total. Course objective was to apply agricultural mechatronics in farm facilities planning. 4 course units that students had to comprehend were incorporation of make education into agricultural technology, basic cultivation techniques, applications of mechatronics in farm facilities, and applications of sensor in agricultures. It was hoped that after learning agricultural mechatronics modular-course with thematic practice, students could know the process of building a farm, enhance job related knowledge and skills, and further incline to work in agricultural industry.

Besides classroom learning, students attended agricultural machinery exhibitions and were expected to understand current applications of agricultural machinery during the process for cultivation, postharvest handling, transportation, sales, and consumption.

\section{3) Lesson plan}

Each unit had its own lesson plan as reference for researchers' teaching. A lesson plan is a teacher's guide for running a lesson, and which contains a list of teaching materials and equipment, required manpower and time, and an instructional component describing the sequence of events that make up the lesson. Therefore, a teacher can take the lesson plan as reference for qualified and smooth teaching.

Course syllabus in this study was designed for modular-course and learning activities objective, inclusive of incorporation of make education into agricultural technology, basic cultivation techniques, applications of mechatronics in farm facilities, and applications of sensor in agricultures.

\section{B. Assessment Scale}

This study employed Bloom's taxonomy for cognitive levels: knowledge, comprehension, application, and analysis to create drafts of preliminary test papers with totally 80 questions, i.e. 20 questions for respective unit: incorporation of make education into agricultural technology, basic cultivation techniques, applications of mechatronics in farm facilities, and applications of sensor in agricultures. Then several teachers and professors of bio-mechatronics department reviewed and revised the drafts to make them formal preliminary test papers. A list of experts is shown in Table I.

TABLE I: LIST OF EXPERTS

\begin{tabular}{ll}
\hline \hline Name & Speciality \\
\hline E01 & $\begin{array}{l}\text { Technological and vocational education, energy } \\
\text { technology, electrotechnology }\end{array}$ \\
E02 & $\begin{array}{l}\text { Agricultural machinery repair, pneumatic control } \\
\text { Fundamentals of electrical engineering, } \\
\text { E03 }\end{array}$ \\
E04 & $\begin{array}{l}\text { Automotive repair, agricultural machinery repair } \\
\text { Computer aided mechanical drawing, } \\
\text { E05 }\end{array}$ \\
\hline \hline
\end{tabular}

Test subjects were seniors of bio-mechatronics department of a skill-based senior high school in central Taiwan. There were 30 students responding to the preliminary test papers.

\section{1) Item analysis}

This study performed SPSS Chinese version to measure item difficulty and item discrimination. The following are principles of removing an item:

a) Difficulty: For multiple-choice items, difficulty index should range from 0.2 to 0.8 , and which was adopted by this study accordingly [5].

b) Discrimination: discrimination idex should be above 0.2 according to [5].

Analysis of the preliminary test papers complied with the above principles. After deleting inappropriate items, there were 63 items left. Then from those 63 items, 5 items were selected for each unit to be compiled formal precourse and postcourse test papers, as shown in appendix. Higher test scores mean higher learning effects, and lower test scores mean lower learning effects.

TBLE II: TABLE OF SPECIFICATIONS

\begin{tabular}{|c|c|c|c|c|c|}
\hline & $\begin{array}{c}\text { knowle } \\
\text { dge }\end{array}$ & $\begin{array}{l}\text { comprehens } \\
\text { ion }\end{array}$ & $\begin{array}{c}\text { applicati } \\
\text { on }\end{array}$ & $\begin{array}{c}\text { analysi } \\
\text { s }\end{array}$ & $\begin{array}{l}\text { total } \\
\text { item }\end{array}$ \\
\hline $\begin{array}{l}\text { Incorporatio } \\
\mathrm{n} \text { of maker } \\
\text { education } \\
\text { into } \\
\text { agricultural } \\
\text { technology }\end{array}$ & $11(4)$ & $5(4)$ & $4(2)$ & & $\begin{array}{l}20 \\
(10)\end{array}$ \\
\hline $\begin{array}{l}\text { Basic } \\
\text { cultivation } \\
\text { techniques }\end{array}$ & $6(6)$ & $6(1)$ & $1(0)$ & $7(3)$ & $\begin{array}{l}20 \\
(10)\end{array}$ \\
\hline $\begin{array}{l}\text { Applications } \\
\text { of } \\
\text { mechatronic } \\
\mathrm{s} \text { in farm } \\
\text { facilities }\end{array}$ & 11 (6) & $6(3)$ & $3(1)$ & & $\begin{array}{l}20 \\
(10)\end{array}$ \\
\hline $\begin{array}{l}\text { Applications } \\
\text { of sensor in } \\
\text { agricultures }\end{array}$ & $13(6)$ & $4(2)$ & $1(1)$ & $2(1)$ & $\begin{array}{l}20 \\
(10)\end{array}$ \\
\hline
\end{tabular}

Note: Numbers outside parentheses are the number of item on preliminary test papers. Numbers inside parentheses are the number of item on formal test papers.

\section{2) Validity analysis}

Test papers in this study were created based on modular-course, teaching content, teaching materials, and relevant books. They were reviewed and revised by experts. Finally, item analysis regarding item difficulty and item discrimination was conducted. Hence, good content validity was established.

\section{3) Reliability analysis}

This study adopted Kuder-Richardson formula 20 (Cronbach's $\boldsymbol{\alpha}$ )to measure consistency among items. Carmines and Zeller considered coefficient values above 0.8 as reliable. Cronbach's $\boldsymbol{\alpha}$ value for precourse learning effects was 0.926, and Cronbach's $\boldsymbol{\alpha}$ value for postcourse learning effects was 0.929, as shown in Table III and Table IV [6]. Results showed that test papers in this study has good internal consistency and reliability [7].

\begin{tabular}{llc}
\multicolumn{3}{c}{ TABLE III: RELIABILITY OF PRECOURSE FORMAL TEST PAPER } \\
\hline \hline Unit & $\begin{array}{l}\text { The Number } \\
\text { of Item }\end{array}$ & KR-20 \\
\hline $\begin{array}{l}\text { Incorporation of maker education into } \\
\text { agricultural technology }\end{array}$ & 5 & \\
$\begin{array}{l}\text { Basic cultivation techniques } \\
\text { Applications of mechatronics in farm } \\
\text { facilities }\end{array}$ & 5 & .926 \\
Applications of sensor in agricultures & 5 & \\
\hline \hline
\end{tabular}


TABLE IV: RELIABILITY OF POSTCOURSE FORMAL TEST PAPER

\begin{tabular}{ccc}
\hline Unit & $\begin{array}{c}\text { The Number of } \\
\text { Item }\end{array}$ & KR-20 \\
\hline $\begin{array}{c}\text { Incorporation of maker education } \\
\text { into agricultural technology }\end{array}$ & 5 & \\
$\begin{array}{c}\text { Basic cultivation techniques } \\
\text { Applications of mechatronics in } \\
\text { farm facilities }\end{array}$ & 5 & .929 \\
Applications of sensor in \\
agricultures
\end{tabular}

\section{RESEARCH RESULTS AND DISCUSSION}

This study adopted SPSS 22 software to run descriptive statistics and paired sample t-test.

\section{A. Descriptive Analysis}

40 students answered two test papers. 28 students $(70 \%)$ passed precourse test, and 36 students $(90 \%)$ passed postcourse test, as shown in Table $\mathrm{V}$ and Table VI. The results in Table VI show that students made greatest progress in unit "applications of mechatronics in farm facilities" with a score of 4.88 indicating that students achieved the best learning effects and might feel interested in this unit. Students made a score of 1.50 in unit "incorporation of maker education into agricultural technology." It meant that student made little progress and obtained poor learning effects from this unit.

\begin{tabular}{ccccc} 
TABLE V: SUMMARY OF AVERAGE SCORES AND PASSED TESTEES \\
\hline \hline Test & $\begin{array}{c}\text { Total } \\
\text { testee }\end{array}$ & $\begin{array}{c}\text { Passed } \\
\text { testee }\end{array}$ & Average & $\begin{array}{c}\text { Percentage } \\
\text { of passed } \\
\text { testee }(\%)\end{array}$ \\
\hline $\begin{array}{c}\text { Precourse } \\
\text { test } \\
\begin{array}{c}\text { Postcourse } \\
\text { test }\end{array}\end{array}$ & 40 & 28 & 74.13 & 70 \\
\hline \hline
\end{tabular}

TABLE VI: SUMMARY OF AVERAGE SCORE IN EACH UNIT

\begin{tabular}{|c|c|c|c|}
\hline Unit & $\begin{array}{l}\text { Ave. } \\
\text { score } \\
\text { on pre- } \\
\text { course } \\
\text { test }\end{array}$ & $\begin{array}{l}\text { Ave. } \\
\text { score on } \\
\text { post- } \\
\text { course } \\
\text { test }\end{array}$ & $\begin{array}{l}\text { Ave. } \\
\text { (pre- } \\
\text { course- } \\
\text { post- } \\
\text { couse) }\end{array}$ \\
\hline $\begin{array}{l}\text { Incorporation of maker } \\
\text { education into agricultural } \\
\text { technology }\end{array}$ & 18.13 & 19.63 & 1.50 \\
\hline Basic cultivation techniques & 17.88 & 21.00 & 3.13 \\
\hline $\begin{array}{l}\text { Applications of mechatronics } \\
\text { in farm facilities }\end{array}$ & 19.25 & 21.75 & 2.50 \\
\hline $\begin{array}{l}\text { Applications of sensor in } \\
\text { agricultures }\end{array}$ & 18.88 & 23.75 & 4.88 \\
\hline Total & 74.13 & 82.25 & 8.12 \\
\hline
\end{tabular}

\section{B. Differnces in Learning Effects}

Paired sample t-test was conducted to assess if there were differences in learning effects after students took agricultural mechatronics modular-course (analysis results shown in Table VII).

TABLE VII: RESULTS OF PAIRED SAMPLE T-TEST

\begin{tabular}{|c|c|c|c|c|}
\hline Unit & Test & Mean & SD & T statistic \\
\hline $\begin{array}{l}\text { Incorporation of } \\
\text { maker education into }\end{array}$ & $\begin{array}{l}\text { Pre-course } \\
\text { test }\end{array}$ & 18.13 & 6.37 & -1.53 \\
\hline
\end{tabular}

\begin{tabular}{|c|c|c|c|c|}
\hline $\begin{array}{l}\text { agricultural } \\
\text { technology }\end{array}$ & $\begin{array}{l}\text { Post-course } \\
\text { test }\end{array}$ & 19.63 & 6.92 & \multirow[b]{2}{*}{$-4.27 * *$} \\
\hline \multirow{2}{*}{$\begin{array}{l}\text { Basic cultivation } \\
\text { techniques }\end{array}$} & $\begin{array}{l}\text { Pre-course } \\
\text { test }\end{array}$ & 17.88 & 7.06 & \\
\hline & $\begin{array}{l}\text { Post-course } \\
\text { test }\end{array}$ & 21.00 & 6.43 & \multirow{3}{*}{$-2.27 *$} \\
\hline \multirow{2}{*}{$\begin{array}{l}\text { Applications of } \\
\text { mechatronics in farm } \\
\text { facilities }\end{array}$} & $\begin{array}{l}\text { Pre-course } \\
\text { test }\end{array}$ & 19.25 & 8.29 & \\
\hline & $\begin{array}{l}\text { Post-course } \\
\text { test }\end{array}$ & 21.75 & 4.74 & \\
\hline \multirow{2}{*}{$\begin{array}{l}\text { Applications of } \\
\text { sensor in } \\
\text { agricultures }\end{array}$} & $\begin{array}{l}\text { Pre-course } \\
\text { test }\end{array}$ & 18.88 & $\begin{array}{l}6.45 \\
8\end{array}$ & \multirow[t]{2}{*}{$-4.45 * *$} \\
\hline & $\begin{array}{l}\text { Post-course } \\
\text { test }\end{array}$ & 23.75 & 6.38 & \\
\hline \multirow{2}{*}{ Whole } & $\begin{array}{l}\text { Pre-course } \\
\text { test }\end{array}$ & 74.13 & $\begin{array}{l}25.9 \\
4\end{array}$ & \multirow[t]{2}{*}{$-4.10^{* * *}$} \\
\hline & $\begin{array}{l}\text { Post-course } \\
\text { test }\end{array}$ & 82.25 & $\begin{array}{l}18.5 \\
7\end{array}$ & \\
\hline
\end{tabular}

From Table VII, it shows that there is a significant difference in almost all units except unit "incorporation of maker education into agricultural technology." The results implicate that students' learning and cognition were highly improved after agricultural mechatronics modular-course was taken, but the reason why students did not achieve higher learning outcomes after taking "incorporation of maker education into agricultural technology" may be that teaching methods need to be adjusted to increase students' interest.

\section{CONCLUSION}

After the implementation of agricultural mechatronics modular-course for 12 weeks, the modular-course on the whole has been proved to have a positive effect on students' learning. Students were passive and distracted in the beginning, but after taking the modular-course, they became actively cooperative. It is hoped that by taking the modular-course, students can learn knowledge of modern mechatronics, learn to respect nature and utilize technology, cultivate their interest in agricultural industry, and cultivate teamwork spirit. This study has concluded that:

\section{A. Agricultural Mechatroincs Modular-Course Has a Positive Effect on Student-Learning}

Analysis results demonstrated that there was a significant positive difference in student-learning after agricultural mechatronics modular-course was applied. Teachers verified the results during classroom instruction and found that students have applied what they learned from the modular-course to thematic practice.

\section{B. "Applications of Sensor in Agriculture" Is More Popular with Students}

Analysis results demonstrated that students achieved the best learning effects in unit "applications of sensor in agriculture" It manifests this unit is more popular with students so an adequate teaching method may be sought from the course design of this unit and be applied to other units. 


\section{REFERENCES}

[1] C. L, Fang, H. H, Huang, C. H. Wang. S. G. Jeang, and K. S. Shiao, "Study on Taiwan agriculture higher education system," Review of Agricultural Extension Science, vol. 19, pp. 61-98, 2002.

[2] S. Y. Xiao, "Micro electromechanical systems - From technology to life," Instrument Technology Research Center Gazette, vol. 98, pp. 12-13, 2010.

[3] X. Q. Xiao, Z. Y. Zhao, S. Q. Xu, X. M. Xu, S. H. Zeng, and W. R. Chen, "A commentary on how to cultivate engineering students the ability of creative thinking by project work," Journal of Industrial Education and Technology, vol. 21, pp. 15-28, 2001.

[4] J. L Tsai and N. M. Lyau, "Developing an Implementation Mechanism for the 'practical project' course in vocational schools," Journal of Technology and Vocational Education, vol. 2, no. 1, pp. 19-34, 2010.

[5] S. Y Guo, Psychology and Educational Test, Taipei City, Taiwan: Jing-Hua, 1999.

[6] E. G. Carmines and R. A. Zeller, Reliability and Validity Assessment, Beverly Hills, CA:Sage, 1979.

[7] M. L. Wu, SPSS \& the Application and Analysis of Statistics, New Taipei City, Taiwan: Acore Imagination International Inc, 2011.

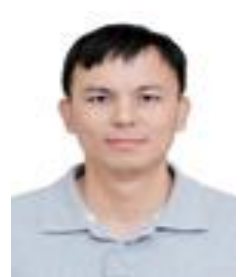

Chih-Ho Nien received M.S. degree at the Chung Chou University of Science and Technology in 2008, and currently is a doctoral student at the Department of Industrial Education from National Changhua University, Taiwan, R.O.C. Since August 2015, he has been a director of Student Affairs in Changhua County Wanxing Junior High School in Taiwan, R.O.C. Since August 2013, he has taught courses in mathematics study in the same school.

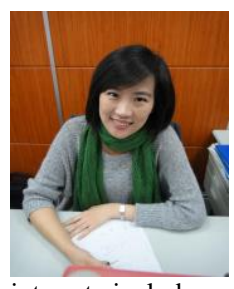

Yu-I Wang is currently a doctoral student in the Department of Industrial Education at National Changhua University in Taiwan and an administrative officer of the College of General Education at National Chin-Yi University of Technology. She received master degree in the Institute of Innovation Technology and Information Management at National Chin-Yi University of Technology. Her research interests include service management, performance evaluation, and quality management. Her research has been published in the journal of Key Engineering Materials and some international conferences.

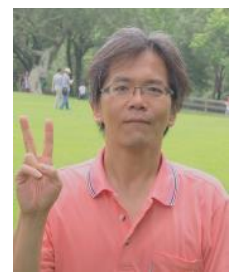

Hung-Yi Lin received M.S. degree at the Department of Industrial Education from National Changhua University in 2006, and currently is a doctoral student at the Department of Industrial Education from National Changhua University, Taiwan, R.O.C. Since August 2013, he has been a director of Academic affairs in National Shiou Shuie Senior Industrial Vocational High School in Taiwan, R.O.C. Since August 1999, he has taught courses in Dept. of Electrical Engineering in the same school.

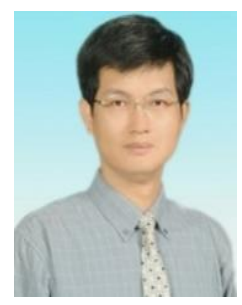

Chin-Wen Liao received both M.S. and Ph.D. in Industrial Education from National Taiwan Normal University, Taiwan, R.O.C. in 1994 and 2002, respectively. Since August 2011, he has been a professor in Department of Industrial Education and Technology at National Changhua University of Education (NCUE) in Taiwan, R.O.C. He teaches courses in technology and vocational education, energy education, course and teaching, organizational learning. His research interests include technology and vocational education, teacher education, energy education of technology, and learning organization. 